\title{
MIECZYSŁAW POLAK \\ »Kurs wiary wspólnotowej« jako pomoc w odkryciu powołania świeckich wiernych we wspólnocie chrześcijańskiej
}

\begin{abstract}
Od czasów II Soboru Watykańskiego Kościół w swoim oficjalnym nauczaniu głosi, że każdy, kto został przyłączony do Kościoła ( $\mathrm{Dz} 2,47)$, powołany jest do tego, aby przyczyniał się do wzrostu Kościoła i do jego ciagłego uświęcania (por. KK 33). Każdy bez wyjątku chrześcijanin powinien mieć żywa świadomość tego, że jest członkiem Kościoła, czyli osobq, której dla dobra wszystkich powierzone zostało oryginalne, niezastapione i ściśle osobiste zadanie (ChL 28). Cechą charakterystyczną wspólnot chrześcijańskich jest między innymi to, że nie ma w nich, tak jak i w calym Kościele takich, którzy nie byliby powołani, którzy zostali pozbawieni osobistej odpowiedzialności za życie i działalność wspólnoty Kościoła ${ }^{1}$. Niewatpliwie wiele powołan świeckich w Kościele pozostaje nie odkrytych, a przez to nie przyczyniaja się one do jego budowy i wzrostu. $W$ apostolstwie indywidualnym sq ogromne bogactwa, które należy odkryć... (ChL 28). Wydaje się, że zbyt mała jest troska współczesnego Kościoła w Polsce, zmierzająca do odkrycia i wykorzystania tego bogactwa powołań, jakimi zostali obdarzeni wszyscy członkowie wspólnot chrześcijańskich. Duszpasterstwo powołań ograniczało się tradycyjnie wyłącznie do powołań kapłańskich, zakonnych i misyjnych. Jest to $\mathrm{z}$ pewnością jedna z przyczyn bierności i powierzchowności znacznej liczby katolików, na którą wskazuje II Polski Synod Plenarny ${ }^{2}$. W niektórych wypadkach przyczyną takiego stanu rzeczy jest brak pomocy duszpaster-

${ }^{1}$ Por. P.M. Zu l e h n e r: Das Gottesgerücht. Bausteine für eine Kirche der Zukunft. Wyd. 6. Düsseldorf 1989 s. 22.

${ }^{2}$ Por. II Polski Synod Plenarny: Potrzeby i zadania nowej ewangelizacji na przełomie II i II Tysiaclecia Chrześcijaństwa, nr 23.
\end{abstract}


skiej w odkryciu powołania, a później często także brak możliwości jego urzeczywistnienia we wspólnocie parafialnej. Niekiedy powołanie świeckich zostaje zawężone tylko do różnych ruchów i stowarzyszeń katolickich, które jednak nie sa podstawowym miejscem realizacji powolania chrześcijańskiego, lecz są niekiedy jakby matkami zastępczymi dla niepłodnej matki wiary parafii ${ }^{3}$. Jedną z możliwości odkrycia swojego powołania w Kościele przedstawia tzw. Podstawowy kurs wspólnotowej wiary (Grundkurs gemeindlichen Glaubens), opracowany w diecezji Passau przez P.M. Zulehnera, J. Fischera i M. Hubera ${ }^{4}$.

\section{Kościół jako wspólnota powołanych}

Jednym z podstawowych założeń Kursu jest odwolanie się do prawdy o powołaniu każdego, kto zostal przylączony do Kościoła (Dz 2, 47). Kościół jest wspólnotą powolanych i nie ma w nim niepowolanych. Każdy, kto należy do Kościoła, czy to świecki, czy duchowny obdarzony został współodpowiedzialnością za misję, jaką ma on do wypełnienia. Zbawcza misja Kościola jest jedna $\mathbf{i}$ jedyna i z zasady uczestniczą w niej wszyscy jego członkowie. Cokolwiek $i \mathrm{~W}$ jakimkolwiek czasie i na jakimkolwiek miejscu pełnione jest w Chrystusie, przez Chrystusa i zmierza do Chrystusa, shuzy urzeczywistnieniu zbawczej misji Kościoła. Podmioty działania Kościoła wewnqtrz i na zewnqtrz, a tym samym $i$ podmioty apostolatu Kościola, stanowiq zawsze całość Ludu Bożego i wszystkich jego członków $w^{5}$.

Świadomość powołania każdego, kto należy do Kościoła była szczególnie wyraźna w pismach Nowego Testamentu, ukazujących sposób życia i myślenia pierwszych wspólnot chrześcijańskich. Żaden z członków Kościoła nie został do niego przyłączony bez potrzeby, przypadkowo. Kościół wtedy żyje, kiedy każdy z jego członków przyczynia się do jego budowania i wzrostu, mając przy tym pełną świadomość tego, że Pierwszym Budowniczym jest Chrystus. Punktem wyjścia (kursu wspólnotowej wiary) jest przekonanie, że budowniczym Kościoła jest dziś sam (Trójjedyny) Bóg: Bóg, który w Chrystusie stał się jednym z nas $i$ pozostaje obecnym w historii przez Ducha Świętego. Ze względu na tę prawdę, czasem zapominanq w codziennym życiu Kościoła (zapomnienie, które poszerza przestrzeń strachu $w$ Kościele) jest on określany starym czcigodnym słowem, mianowicie »ekklesia«, czyli »Wspólnota powołanych ${ }^{6}$. Kościól jest zatem

${ }^{3}$ Por. P.M. Z u 1 e hn e r: Pastoraltheologie. T. 2. Gemeindepastoral. Wyd. 3. Düsseldorf 1995 s. $152-154$.

${ }^{4}$ P.M. Z u leh n e r, J. F i s ch er, M. Huber: "Sie werden mein Volk sein". Grundkurs gemeindlichen Glaubens. Wyd. 5. Düsseldorf 1990.

${ }^{5}$ A.J. S k o w r o n e k: Z Kościolem w trzecie tysiqclecie. Czego oczekuje od Kościoła? Włoclawek 1999 s. 59.

${ }^{6}$ P.M. Z u l e h n e r: Das Gottesgerücht, dz. cyt., s. 19. 
wspólnota powołanych z całej społeczności ludzkiej, która nosi zaszczytne miano „Lud Boży”. To powolanie nie odnosi się tylko do własnego zbawienia, ale także do zbawienia innych, do tego, aby świadectwem i slowem oglaszać wszystkim ludziom Boży zamiar wobec czlowieka jakim jest zbawienie wszystkich w Chrystusie?

Kościół urzeczywistnia swoją misje przez to, że wszyscy ci, którzy są powolani przez Boga, swoje powolanie rozpoznają i przyjmą i będą je realizować w życiu i działalności Kościoła. Podstawowym i wspólnym powołaniem wszystkich ochrzczonych jest powołanie do miłości, z którego w konsekwencji wyplywa powołanie do świętości. Wszyscy wierni z tytułu swej przynależności do Kościoła otrzymuja powszechne powołanie do świętości i w nim współuczestniczq. Sq nim objęci na pełnych prawach i na równi ze wszystkimi innymi członkami Kościoła także świeccy (ChL 16). Powołanie do miłości i do świętości sa jakby dwoma aspektami jednego podstawowego powolania, poniewaz miłość jest doskonałym wypełnieniem prawa (por. Kol 3, 14; Rz 13, 10) .

Analizując teoretyczne założenia Kursu jak i sposób jego realizacji można stwierdzić, że wpisuje się on w caly nurt pastoralny, zmierzający do przezwyciężenia w Kościele tzw. „podstawowej schizmy pastoralnej”. Pojęcie to zamierza ując owq formę Kościoła, w której nie wszyscy sq powołanymi i podmiotami, ale sq w nim powołani i niepowołani, podmioty i przedmioty, tacy którzy się troszczq i inni, o których się troszczy, Kościół nauczajacy i Kościół słuchajqcy, kościelni przełożeni i duchowni poddani, obsługujqcy i obsługiwani. Do rzędu tych przeciwstawnych par należy także para »kler $i$ świeccy« ${ }^{9}$. Powstanie powyższego rozumienia Kościoła uwarunkowane jest względami historycznymi, lecz wymaga dziś niewątpliwie zmierzania do jego przezwyciężenia ${ }^{10}$.

Twórcy Kursu wspólnotowej wiary starają się rozszerzyć znaczenie terminu „powołanie duchowne”. Odnosza je, w szerszym znaczeniu do każdego chrześcijanina. Tym zatem co należy wspierać, aby Lud Boże w znaczeniu II Soboru Watykańskiego był żywy i zdolny do działania sq »powołania duchowne« wszystkich członków Kościoła (z tego tė̇ powodu będzie w przyszłości więcej »powołań duchownych ; ponieważ bez duchownych powolań wielu brakuje owocnej gleby dla »duchownych powołań «apłańskich i zakonnych) ${ }^{11}$. Właściwe rozumienie powyższego terminu nie ma na celu deprecjacji znaczenia powołań kapłańskich czy zakonnych, ale zwrócenie uwagi na to, że to podstawowe powolanie każdego

\footnotetext{
${ }^{7}$ Por. tamże, s. 19 .

${ }^{8}$ P.M. Zu le h n e r: Pastoraltheologie. T. 2. Gemeindepastoral, dz. cyt., s. 130.

${ }^{9}$ Por. tamże, s. 130.

${ }^{10}$ Por. tamże, s. $131-140$

${ }^{11}$ P.M. Z u le h n e r: Das Gottesgerücht, dz. cyt., s. 19.
} 
chrześcijanina jest ostatecznie powołaniem duchownym, $\mathrm{z}$ tej racji, że jest ono istotnym i nieodlqcznym skladnikiem nowego życia otrzymanego wraz z chrztem, a więc konstytutywnym elementem ich godności (ChL 17).

Analizując zatem zarówno biblijne świadectwa jak i wspólczesną, oficjalna Naukę Kościoła nie da się zaprzeczyć tezie, że Kościól jest wspólnota powołanych i każdy chrześcijanin obdarzony został Przez Boga niepowtarzalnym powołaniem, którego odczytanie i realizacja stają się podstawą wszelkiej działalności apostolskiej. Z powołaniem związana jest współodpowiedzialność za Kościół i jego misję. Stąd nie można mówić tylko o współpracy wiernych świeckich z hierarchia, o współpracy kapłanów czy katechetów z biskupem, ale o ich współodpowiedzialności. Nie chodzi tu tylko o słowa, ale o uznanie równej godności i przyjęcie podstawowego założenia, że tym który buduje i prowadzi Kościól jest ostatecznie Bóg.

\section{Zdolność każdego chrześcijanina do odkrycia i realizacji swojego powolania}

Kolejnym założeniem Kursu wiary wspólnotowej jest przekonanie, że każdy chrześcijanin zdolny jest do odkrycia swojego powołania. Autorzy przyjmuja założenie, że Bóg jest obecny w życiu każdego czlowieka, że historia jego życia jest tą samą historia, jaką Bóg z nim pisze. Historia każdego człowieka jest dlatego od samego poczqtku historiq zawsze wiernego Boga (Pwt 32, 4; 2 Tym 2, 13) $z$ nim $^{12}$. Doświadczenie Boga, jego działania w życiu jest podstawa do nawiązania z Nim dialogu, a dalej do odkrycia tego, czego Bóg oczekuje ode mnie w swoim Kościele, co zamierzył uczynić ze mna powołując mnie do swego Kościoła. Każdy czlowiek jest zdolny poprzez analizę swojego życia, codziennego życia zauważyć w nim szczególne momenty, w których doświadczył Bożego dzialania. Kurs wspólnotowej wiary jest zatem zaproszeniem do poszukiwania Boga, który jest wciaż obecny w historii życia człowieka i pozostaje obecny także w jego przyszłości. Stąd wpisuje się on w koncepcję tzw. „duszpasterstwa mistagogicznego" ${ }^{13}$. Mistagogia jest bowiem wprowadzeniem w doświadczenie Boga i Jego zbawczego planu, wprowadzeniem w tajemnicę, którą od samego początku jest życie człowieka. Stąd wprowadza ona człowieka w obszar, w którym stawia on sobie egzystencjalne pytania, dotyczące jego relacji z Bogiem ${ }^{14}$.

${ }^{12}$ P.M. Z u l e h n e r: Das Gottesgerücht, dz. cyt., s. 22.

${ }^{13}$ Por. Mystagogie. W: Lexikon für Theologie und Kirche. Wyd. 3. T. 7. Red. W. Ka s p e r. Freiburg, Basel, Rom, Wien 1998 s. 571. Więcej na temat duszpasterstwa mistagogicznego zob. np.: Mystagogische Seelsorge. Red. S. K n o b l o c h, H. H a s l i n g e r. Mainz 1991.

${ }^{14}$ Por. Mystagogische Seelsorge, dz. cyt., s. 78-79. 
Jednym zatem z ważniejszych zadań Kursu jest to, aby każdy uczestnik nauczył się wpierw postawić pytanie: Co Bóg zamierzył dla mnie w swoim Kościele? Rola prowadzącego porównana może zostać do biblijnego kapłana Eliasza (1 Sam 3,1-19), który przy powolaniu Samuela pomaga zinterpretować mu jego doświadczenie religijne, wskazując na to, że to właśnie Bóg, jest tym, który go powołuje. Odkrycie powołania jest zobowiązujące. Łączy się z podjęciem za nie odpowiedzialności. Jest to ostatecznie odpowiedzialność za życie i działanie Kościoła. Chrześcijanin, który przyjmuje swoje powołanie zdaje sobie $\mathrm{z}$ tego sprawę, że będzie musiał kiedyś odpowiedzieć przed Bogiem na pytanie: Co zrobileś ze swoim „duchownym powołaniem”? (por. Mt 25, 14-30) ${ }^{15}$.

Odkrycie powołania dokonuje się najpierw poprzez refleksję nad własną historią życia, jako historią wiary. Dostrzeżenie w tej historii śladów obecności Boga, a jeszcze bardziej Jego ciagłej obecności w ludzkiej, osobistej historii stanowi nieodzowny moment na drodze odczytywania powołania. Refleksja na własnq historiq wiary, przypomnienie jej sobie, jakby ponowne jej wewnętrzne przeżycie, wyrażenie jej i wypowiedzenie sq pierwszymi krokami „Kursu wspólnotowej wiary ${ }^{, 16}$.

Wiara w możliwość odczytania swojego powołania podkreśla znaczenie osobistej decyzji człowieka, zakładającej jego wolność, a zarazem potwierdza przekonanie o obecności i działaniu Boga w życiu człowieka od samego początku jego życia. Powołanie nie jest zatem zewnętrznym aktem, ale należy do istoty bycia człowiekiem, a jeszcze bardziej chrześcijaninem. Z tego względu pomoc duszpasterska w odkryciu powołania nie jest „importem Boga”, przekazaniem czegoś z zewnątrz, ale postawieniem czlowieka w obliczu tajemnicy Boga, który $w$ jego życiu jest obecny już na długo przed naszym dotarciem do niego ${ }^{17} . Z$ bardziej konkretnego punktu widzenia oznacza to, że człowiek jako taki ma $W$ sobie iskrę Bozz - własnq zdolność realizowania obrazu Boga w sobie. Powinien tylko uruchomić, by tak powiedzieć wszystkie swoje talenty i sily celem wykonania tej samorealizacji. Sposób zaś w jaki to czyni, przedstawia ponownie jego osobistq wielkość w oczach Boga. W rzeczy samej człowiek otrzymał wolność wypełniania swego powołania poprzez pełne wykorzystanie swej twórczej energii. Bóg zasiewa w nas swe ziarno; człowiek ze swej strony rozwija, dzięki lasce Boga - a więc poprzez dialog z Bogiem - Jego obraz w sobie ${ }^{18}$.

\footnotetext{
${ }^{15}$ Por. P.M. Z u 1 e h n e r: Das Gottesgerücht, dz. cyt., s. 22.

${ }^{16}$ P.M. Z u le h n e r, J. F i s c h e r, M. H u ber: "Sie werden mein Volk sein”. Grundkurs gemeindlichen Glaubens, dz. cyt., s. 86.

${ }^{17}$ Denn du kommst unserem Tun mit deiner Gnade zuvor. Zur Theologie der Seelsorge heute. P.M. Zu l e h n e rim Gespräch mit Kar 1 Ra h n e r. Ostfildern 2002 s. 68.

${ }^{18} \mathrm{~J}$. V a n d e r V lo e t: Obraz człowieka jako fundament pedagogii. „Communio”. Wydanie polskie. R. 12: $1992 \mathrm{nr} 3(69)$ s. 6-7.
} 
Powyższe rozważania warunkują także postawę i zadania prowadzących Kurs. Ich dzialanie pedagogiczne musi uwzględnić ową zdolność człowieka do rozpoznania swojego powolania. Musza zrezygnować $\mathrm{z}$ pokusy ingerencji w relację między Bogiem i czlowiekiem, a stosować zasadę pomocniczości, wprowadzenia, towarzyszenia $\mathrm{w}$ samodzielnym dochodzeniu każdego do prawdy o Bogu, o osobie i swoim powołaniu. Akt wychowawczy polega, w tym sensie, na wprowadzeniu człowieka $w$ prawdę. Pedagog powinien nauczyć rozumieć, iż prawda każdego człowieka znajduje się w nim samym, gdyż jest ona z Boga i jest w Bogu. Nie może zdziałać czegoś więcej, ale nie powinien też czynić mniej. Relacja pedagogiczna jest więc przede wszystkim dialogiem między Bogiem $i$ człowiekiem, ułatwianym przez pedagoga ${ }^{19}$.

\section{Podstawowe metody realizacji Kursu}

Odkrycie wlasnego powołania, które wiąże się z pogłębioną refleksją nad osobistym życiem i wiara, wymaga określonych warunków zewnętrznych. Dobrze jest, kiedy odejdzie się od codziennego zgiełku (Exodusi) i w ciszy (na pustyni) skieruje się ku sobie, zobaczy swojq wlasnq historię życia i uczy się odczytywać i rozumieć jq jako historię Boga ze mnq i mojq z nim². Podobnie jak król Salomon (1Krl 3, 2-11), który udał się do Gibeonu i tam przedstawiając Bogu swoja prośbę poprzedził ją spojrzeniem na historię życia, swoich przodków i własna. To biblijne wydarzenie stanowi pewien model metodyczny Kursu. Salomon wyrusza w poszukiwaniu swojego powołania. Podstawowym założeniem do odkrycia przez Salomona swojego powolania jest to, że tak poważnie traktuje on swoje zadania, swój zawód, że musi na jakiś czas je przerwać, odejść od nich, pozostawić je, aby doświadczyć, co powinien czynić. Pierwszym elementem metody kursu jest przerwanie swojej codzienności, wyjazd, odejście od tego wszystkiego, co mnie na co dzień zajmuje. Wyjechać! $Z$ innymi udać się do miejsc, domów, gdzie od dawna stawia się to pytanie: Panie, co chcesz abym czynit? Krok ten jest najtrudniejszy ${ }^{21}$.

Ten, kto opuszcza swoją codzienność traci początkowo język, którym się zazwyczaj posługuje: język techniczny, funkcyjny, instrumentalny, tylko odtwarzający i powtarzający. Zyskuje jednak nowy, przy pomocy którego może opowiedzieć o swoich doświadczeniach wiary. To druga część metody Kursu: opowiedzieć. Nie tylko liczyć składke i ilość ludzi na mszy św., ale opowiedzieć historię własnego życia wiary ${ }^{22}$. Doświadczenie Kursu wskazuje na dużą różno-

\footnotetext{
${ }^{19}$ Por. tamże, s. 9.

${ }^{20}$ P.M. Z u le h n e r: Das Gottesgerücht, dz. cyt., s. 23.

${ }^{21}$ P.M. Z u leh ner, J. Fis ch e r, M. H u ber: "Sie werden mein Volk sein”. Grundkurs gemeindlichen Glaubens, dz. cyt., s. 92.

${ }^{22}$ Tamże, s. 94.
} 
rodność opowiadanych historii. Każdy ma coś do opowiedzenia. Każdy jest autorem: twórcq swojej historii, jest autorytetem, jest niezastapiony i konieczny $w$ identyfikacji historii wiary, drogi wiary wspólnoty. Nic nie jest banalne, co nie mogłoby być opowiedziane jako autentyczny materiał pewnego ludzkiego życia ${ }^{23}$. Opowiadanie należy do chrześcijańskiej Tradycji. W Starym Testamencie opowiadanie i wspominanie wielkich dzieł Boga miało ważne znaczenie. Chrześcijańskie głoszenie słowa jest opowiadaniem o Jezusie Chrystusie. Kto zatem opowiada, wpisuje się $w$ dobrq Tradycję. Swoim własnym rozdziałem kontynuuje wielkq historię Boga z Jego ludem²4.

Ten etap kursu można nazwać czytaniem tzw. „małego Pisma świętego”. Wychodzę od tego - stwierdza jeden z współtwórców „Kursu” - że każdy chrześcıjanin ma przy sobie Pismo św., lepiej: ma w sobie i przyjmuje to, że jego życie pisane jest rękq Boga, a zatem jest historiq zbawienia ${ }^{25}$.

Każda historia osobistej wiary powinna zostać w następnym kroku Kursu skonfrontowana $\mathrm{z}$ tekstami i obrazami różnych biblijnych historii wiary i powolań. Odnaleźć swoją własną historię wiary w Biblii. Znaleźć jej wyraz w biblijnych opowiadaniach, np. Abrahama, Mojżesza, Samuela, Maryi, Piotra, Pawla z Tarsu, Szymona z Cyreny, Magdaleny itd. Na podstawie historii powołania św. Pawła (Dz 22, 6-16) można postawić sobie przykładowe pytania takie jak np.: Czy w mojej historii wiary znalazłem się kiedyś pod Damaszkiem? Czy był w moim życiu jakiś Hananiasz? Czy historia Pawła mogłaby być historią mojego powołania? Trzecim krokiem metody Kursu jest zatem otwarcie Pisma św. Paralelnie do poprzedniego kroku można nazwać ten etap czytaniem „wielkiego Pisma świętego". Kto odkrywa siebie w Piśmie św. ten chce je czytać, coraz bardziej je poznawać, aby poznać siebie.

Czytanie Pisma św., odkrywanie w nim własnej historii wiary prowadzi w konsekwencji do konfrontacji z rzeczywistością, z dniem dzisiejszym mojej wiary. Otwiera to dobra przestrzeń do postawienia sobie podstawowego pytania: Panie, co mam dalej czynić? Postawienie tego pytania i to zarówno na płaszczyźnie indywidualnej, jak i wspólnotowej (najlepiej wspólnoty parafialnej) jest kolejnym krokiem (metoda) Kursu. Pytania dotyczqce zawodu i wyboru partnera, przeżywania dnia codziennego i świqtecznego, rozwiqzywania problemów $i$ przezwyciężania konfliktów, całej, ciqgle nowej organizacji własnego życia - to sq tematy poruszane na tym etapie ${ }^{26}$.

\footnotetext{
${ }^{23}$ Tamże, s. 93.

${ }^{24}$ Tamże, s. 94.

${ }^{25}$ Tamże, s. 94.

${ }^{26}$ Tamże, s. 97.
} 
Ostatnią częścia Kursu jest świętowanie swojego powolania. Jest to pierwsza odpowiedź na jego odczytanie - wdzięczność wobec Boga za dar powołania. Najczęściej dokonuje się ono w liturgii, która jest „służbą Bożą” (Gottes Diensi). Dlatego jest ona wyrazem podziękowania Bogu, za służbę, za powołanie: dzię kujemy Tobie, że nas wybrałeś, abyśsmy stali przed Tobq i Tobie shizylit .

Od strony praktycznej przebieg Kursu przedstawia się następująco ${ }^{28}$. Uczestnicy powinni najpierw, każdy dla siebie przyjrzeć się swojej wlasnej historii życia i zobaczyć jak ta historia życia jest równocześnie historią wiary, historią Boga z człowiekiem. Powinni przy tym zobaczyć np. jakie modlitwy stały się dla nich szczególnie ważne, kto ich nauczyl, czy przypominają sobie religijne książki z dzieciństwa, które miały dla nich znaczenie, jak rozwijała się ich wiara, jaka rolę w tym rozwoju odegrala ich własna wspólnota parafialna.

Następnie uczestnicy dzielą się na małe grupy, dwie trzy osoby i opowiadaja swoje historie wiary. Pozwalaja w ten sposób spojrzeć innym na tę historię. Wspólne dzielenie się historią wiary czy jej fragmentami pozwala głębiej zrozumieć konkretne sytuacje życia, indywidualny ksztalt wiary drugiego czlowieka. Dalej każdy znów dla siebie powinien znaleźć biblijny wyraz jego historii wiary: wydarzenie, postać, zdanie. Osobista historia wiary zostaje wtedy „przyporządkowana" wielkiej, biblijnej historii wiary Ludu Bożego, a ostatecznie Ewangelii. Odniesienie własnej historii wiary do Biblii jest pewną korektą, pozwoleniem na biblijną ocenę moich doświadczeń. To jakby doświadczenie „kryzysu" w jego biblijnym rozumieniu, założenia koniecznego do prawdziwego odnowienia życia ${ }^{29}$.

W drugiej części Kursu analizuje się historię wiary wspólnoty, w której żyje każdy z uczestników. Najczęściej jest to wspólnota parafialna. Własna historia wiary, zinterpretowana w świetle słowa Bożego zostaje teraz odniesiona do historii Kościola, która konkretyzuje się w historii wspólnoty (dla większości parafialnej). Konfrontacja własnej historii $z$ historią wiary wspólnoty prowadzi do postawienia pytania o dzisiejsze uwarunkowania i możliwości realizacji swojego powołania. Ostateczne pytanie Kursu, na które w jego końcowej fazie uczestnicy poszukuja odpowiedzi brzmi: Co zamierzył dalej Bóg dla mnie i dla mojej wspólnoty parafialnej ${ }^{30}$.

${ }^{27}$ Por. Il Modlitwa Eucharystyczna.

${ }^{28}$ Por. P.M. Z u le h n e r, J. F i s c h e r, M. H u b e r: "Sie werden mein Volk sein". Grundkurs gemeindlichen Glaubens, dz. cyt., s. 84 .

${ }^{29}$ Por. tamże, s. 87.

${ }^{30}$ Por. tamże, s. 88. 


\section{Niektóre trudności i potrzeba ich przezwyciężenia}

Nikt dziś w zasadzie nie kwestionuje teorii o powołaniu wiernych świeckich w Kościele. Inaczej nie byłby zgodny z oficjalnym Nauczaniem Kościoła. W teorii przyznaje się świeckim właściwe im miejsce i zadania w życiu Kościoła. Niestety teoria ta nie zawsze, chyba zbyt rzadko znajduje potwierdzenie w praktycznej działalności Kościoła. Pierwszą trudnościa jest praktyczne zawężenie pojęcia wierny świecki do wąskiej grupy bardziej zaangażowanych w życie Kościoła, należących do różnych ruchów i stowarzyszeń katolickich. Wprowadza to kolejny podział w Kościele na duchownych, świeckich i tzw, „ekspertów” ${ }^{31}$. Stąd pojawia się też dziwne w kościelnym języku określenie - „elity”. Można je znaleźć zarówno w dokumentach lokalnych Kościołów, jak i w nauczaniu niektórych biskupów ${ }^{32}$. Używanie takiego określenia $w$ języku kościelnym nie jest $w$ pełni uzasadnione i może też powodować kolejne podziały w Kościele i zwalnianie $\mathrm{z}$ odpowiedzialności za niego wszystkich ochrzczonych. Doświadczenia wielu uczestników Kursu, po ich powrocie do parafii świadcza o braku wiary zwlaszcza niektórych duchownych, że tzw. „zwykły katolik” może powiedzieć coś w sprawach wiary, mieć wizję rozwoju parafii. Proboszcz niedowierza za bardzo ludziom $w$ sprawach wiary. Musiałby za nich mówić fachowiec ${ }^{33}$. Podstawową sprawą byloby najpierw przezwyciężenie w sposobie myślenia kościelnej hierarchii naszkicowanych powyżej podziałów, zrozumienie, że nikt w Kościele, w parafii nie jest przypadkiem, że każdy ma swoje powolanie i zdolny jest je odczytać i realizować. Najczęściej wiele powolań nie jest realizowanych wskutek braku możliwości ich realizacji. Identyfikacja poszczególnych chrześcijan ze wspólnotą rośnie przez partycypację.

Pewną trudność w realizacji powyższej propozycji Kursu wspólnotowej wiary stanowi też pojawiająca się niechęć do mówienia o sprawach wiary. Nie tylko w minionych czasach dążono do tego, aby wiara byla sprawą prywatną. Także i dziś, i to w Kościele niechętnie rozmawia się o wierze, o jej doświadczeniach, o tym, co Pan Bóg uczynił w życiu czlowieka. Tzw. „świadectwa” jakie pojawiaja się przy okazji różnych rekolekcji, działań ewangelizacyjnych dotyczą najczęściej różnych ekstremalnych historii ludzkiego życia. Nie ma w nich miejsca dla tzw. „zwykkych historii wiary”. I tu znów pojawiają się jakby „eksperci”, ci którzy są zapraszani, aby dawać wobec innych świadectwo. Nie kwestionując wagi

${ }^{31}$ Por. P.M. Z u 1 e h n e r: Pastoraltheologie, dz. cyt., s. 136-138.

${ }^{32}$ Dyrektorium katechetyczne Kościola katolickiego w Polsce (2001) nauczając o katechezie dorosłych zwraca uwagę na to, że prowadząc masowe duszpasterstwo nie można zaniedbać troski o elity (por. nr 101). Podobnie o Akcji Katolickiej jako o apostolskiej elicie świeckich wypowiada się bp P. J a r e ck i - por. T e n ż e: Akcja Katolicka - testament Asystenta - satysfakcja, niepokój. nadzieja. „Wiadomości Archidiecezji Gnieźnieńskiej”. R. 2003 nr 9 s. 616.

${ }^{33}$ P.M. Z u l e h n e r, J. F i s c h e r., M. H u b e r, dz. cyt., s. 88. 
tych działań, ich wpływu na innych można jednak niekiedy odnieść wrażenie, że tylko ten, kto miał jakieś dramatyczne doświadczenia życiowe jest zdolnym i odpowiednim do dzielenia się wiara. I znów zawęża się krag tych, którzy są zdolni wnieść swój wkład w życie Kościoła.

Praca duszpasterska powinna zatem skierować się najpierw w stronę uświadamiania wszystkim wiernym świeckim ich niezbywalnego i niezastapionego powołania, a następnie w kierunku pomocy w jego odczytaniu. Pomoc ta mogłaby być realizowana poprzez przejęcie przedstawionej powyżej propozycji kursu wspólnotowej wiary. Najlepiej gdyby wzięli w nim udział parafianie wraz z ich proboszczem. Podzielenie się odpowiedzialnością za Kościół, za wspólnotę parafialną odciążyłoby wielu duchownych z niemożliwej często do udźwignięcia w pojedynkę odpowiedzialności. Dałoby także wyraz wierze w Kościół jako wspólnotę powołanych, którą kieruje Bóg. Udzielony każdemu ochrzczonemu Duch Święty uzdalnia nie tylko do wspólpracy, ale także do współodpowiedzialności. Ten sam bowiem Duch, który kieruje Kościołem i mu przewodzi, uposaża w rozmaite dary hierarchiczne i charyzmaty wszystkich ochrzczonych, wzywajqc każdego $z$ nich do tego, by był $w$ sobie właściwy sposób aktywny $i$ współodpowiedzialny (ChL 21).

Przedstawiona powyżej koncepcja Kursu wspólnotowej wiary jest z pewnością jedną $z$ wielu możliwości pomocy świeckim w odczytywaniu i podejmowaniu ich powołania w Kościele. Wskazuje ona przede wszystkim na potrzebę rozszerzenia tzw. powołaniowej działalności Kościoła. Ograniczenie jej tylko do powołań kapłańskich i zakonnych jest niewatpliwie zaprzeczeniem tezy o Kościele jako wspólnocie powołanych. Może także prowadzić w konsekwencji do tego, że wiele darów, charyzmatów i powołań, jakie daruje Kościołowi Bóg zostaje niezrealizowanych. A przecież zbawczq misje Kościoła wświecie realizujq nie tylko ci, którzy czyniq to na mocy święceń, ale takìe wszyscy świeccy, którzy na mocy Chrztu i specyficznego powołania uczestniczq - każdy w sobie właściwym stopniu - w kapłańskim, prorockim i królewskim urzędzie Chrystusa (ChL 23). 